\title{
Storage Time: Influence of Nano-ZnO and Soft-Sterilization on Biophysical and Quality Attributes of Canned Cowpea (Vigna unguiculata, TN 5-78)
}

\author{
Moutaleb Oumarou Hama ${ }^{1,2}$, Issoufou Amadou ${ }^{1,2}$, Tijani Amza ${ }^{1,2}$, Cheikna Daou ${ }^{3}$ \& Min Zhang ${ }^{1}$ \\ ${ }^{1}$ State Key Laboratory of Food Science and Technology, 1800 Lihu Road, Wuxi 214122, P. R. China \\ ${ }^{2}$ Département des Sciences et Techniques de Productions Végétales, Faculté d'Agronomie et des Sciences de \\ l'Environnement, Université de Maradi, BP 465, Maradi, Niger \\ ${ }^{3}$ Institut des Sciences Appliquées, Université des Sciences, des Techniques et des Technologies de Bamako, \\ Mali
}

Correspondence : Prof. Min Zhang, State Key Laboratory of Food Science and Technology, 1800 Lihu Road, Wuxi 214122, P. R. China. Tel: 86-510-8587-7225. E-mail: min@jiangnan.edu.cn

\author{
Received: March 2, 2014 Accepted: March 23, 2014 Online Published: March 26, 2014 \\ doi:10.5539/jfr.v3n3p10 URL: http://dx.doi.org/10.5539/jfr.v3n3p10
}

\begin{abstract}
Cowpea seeds can be cooked in the dried form, sprouted, or ground into flour. This study is to investigate effect of soft-sterilization and nano-ZnO treatment on canned cowpea (TN 5-78) biophysical and quality attributes during 10 months of storage. Cowpea was blanched, ultrasonicated with nano-ZnO solution $0.025 \%$ (w/v) added prior to canning at $110{ }^{\circ} \mathrm{C}$ for $15 \mathrm{~min}$ and analyzed every 2 months up to 10 month at ambient storage. Total mold and yeast count were below the limits of detection for nano- $\mathrm{ZnO}$ treated samples and control over the storage period though, some colonies of mesophilic bacteria were observed in the untreated samples at the 8th and 10th month of storage. There are significant differences $(\mathrm{P}<0.05)$ between the treated samples and untreated one at the 10th month of storage for the pea's firmness. No significant differences was noticed between the samples from the initial analysis to the end of storage time for the leached solids percentage $(\mathrm{P}<0.05)$. Moreover, slight change in protein content and $\mathrm{pH}$ values were also found. The overall acceptability score of nano- $\mathrm{ZnO}$ treated samples remained in a good range up to $10^{\text {th }}$ month of storage whereas, untreated samples was under acceptation level. Therefore, $\mathrm{ZnO}$ nanoparticules combined with heat can be a possible alternative approach to can foods that the quality attributes are altered by conventional thermal sterilization.
\end{abstract}

Keywords: cowpea, soft sterilization, nano- $\mathrm{ZnO}$, sensory, quality

\section{Introduction}

Cowpea (Vigna unguiculata) is a grain legume, with various ways of utilization in traditional and modern food processing across the world. Cowpea seeds can be cooked in the dried form, sprouted, or ground into flour (Odedeji \& Oyeleke, 2011). Referred to as "poor man's meat" by West Africans cowpea is of considerable importance in many African countries as a nutritious leguminous crop providing an alternative source to animal protein (Afoakwa \& Yenyi, 2006). Sefa-Dedeh et al. (2001) reported that cowpea contributes up to $80 \%$ of the total dietary protein intake in some parts of West Africa. In addition to its nutritional quality, cowpea presents also some health benefits. Gutiérrez-Uribe and Serna-Saldívar (2011) found that whole cowpeas are a good source of phytochemicals inhibiting in vitro cancer cell growth.

Depending on areas, cowpea is consumed in different ways. Akara (fried cowpea paste) and moin-moin (steam cowpea paste) are found to be the main cowpea-based foods in West African countries (Amonsou, Sakyi-Dawson, \& Saalia, 2010). Previous studies (Odedeji \& Oyeleke, 2011; Sefa-Dedeh, Sakyi-Dawson, \& Afoakwa, 2001) have shown that the consumption of beans is curtailed because of the long cooking time needed to achieve the desired palatability and digestibility. Thus, it is important to develop new cowpea-based foods that are easy to prepare. Sefa-Dedeh et al. (2003) reported that canning is proven to give cowpea a longer shelf life. Cooking and industrial dehydration increases the nutritional value of legumes by inactivating most of the anti-nutritional 
factors present, but also alters the functional properties and microstructural characteristics of legume proteins (Antonia, Jiménez, \& Martínez-Tomé, 2009; Foh, Wenshui, Amadou, \& Jiang, 2012). Color and texture which are the most important quality attributes of processed foods change during thermal processing (Leadley, Tucker, \& Fryer, 2008; Sankhon, Amadou, Yao, Wang, Qian, \& Mlyuka, 2014). Thus, it's a challenge for food engineers to find the best processing condition to process food products with an acceptable quality.

Zinc oxide $(\mathrm{ZnO})$ nanoparticules are increasingly been used in the food industry mainly because of their antimicrobial property (Jin, Sun, Su, Zhang, \& Sue, 2009; Tayel, El-Tras, Moussa, El-Baz, Mahrous, Salem, et al., 2011; Xie, He, Irwin, Jin, \& Shi, 2011). (Emamifar, Kadivar, Shahedi, \& Soleimanian-Zad, 2010) found that low-density polyethylene nano composite packaging materials containing silver and $\mathrm{ZnO}$ nanoparticles is able to extend the shelf-life of fresh orange juice during cold storage $\left(4{ }^{\circ} \mathrm{C}\right)$. Li et al. (2011) had developed a novel polyvinyl chloride film coated with nano-ZnO particles. Recently, Meng et al. (2014) found that combined application of ultrasound and nano- $\mathrm{ZnO}$ coating is capable of effectively delaying the senescence and significantly extending the storage life of fresh-cut kiwifruit. However, research by Wang et al. (2008) has reported nano- $\mathrm{ZnO}$ regulated low doze $\mathrm{LD}_{50}$ to be $20-\mathrm{nm} \mathrm{ZnO}$ is greater than $5-\mathrm{g} / \mathrm{kg}$ body weight and belongs to unclassified toxicity according to the Globally Harmonized Classification System (GHS) for the classification of chemicals. Therefore, it was concluded that 20 - and $120-\mathrm{nm} \mathrm{ZnO}$, to be relatively nontoxic.

However, up to date, there are no publications reporting the combination of nano- $\mathrm{ZnO}$ and heat to process soft sterilized foods, therefore the objective of this study is to investigate the influence of combined effect of nano- $\mathrm{ZnO}$ and soft sterilization upon long period of storage on the quality factors such as microbial growth, leached solid, firmness, $\mathrm{pH}$, proximate composition and sensory attributes of soft sterilized TN 5-78 cowpea variety.

\section{Material and Methods}

\subsection{Materials}

Zinc oxide $(\mathrm{ZnO})$ nano-particules were purchased from Sigma-Aldrich and the cowpea variety TN 5-78 was obtained from a seed production company "EntrepriseSemencièreAlheri" (Niamey, Niger). All other reagents were of analytical grade.

\subsection{Samples Treatments}

Cowpea seeds were firstly sorted to remove under quality peas and washed with deionized water then soaked in sodium hexametaphosphate $\left[\left(\mathrm{NaPO}_{3}\right)_{6}\right] 0.5 \%(\mathrm{w} / \mathrm{v})$ solution for $12 \mathrm{~h}$. The peas were then blanched in deionized water for $5 \mathrm{~min}$ at $90{ }^{\circ} \mathrm{C}$ afterwards; the blanched peas were versed in glass containers. The nano-ZnO solution $0.025 \%(\mathrm{w} / \mathrm{v})$ used to fill the glass containers in a ratio of 1:3 (solid-liquid) was previously ultrasonicated for 20 $\mathrm{min}$. The sealed containers were canned in a vertical rotor using optimized temperature-time $\left(110^{\circ} \mathrm{C}\right.$ and $\left.15 \mathrm{~min}\right)$. Canned samples were cooled at room temperature $\left(25^{\circ} \mathrm{C}\right)$ and one batch of six cans $(3$ cans for both treated and untreated samples) was selected randomly and analyzed. The remained cans were stored at room temperature (25 ${ }^{\circ} \mathrm{C}$ ) and one batch was randomly selected to perform the analysis each 2 months over 10 months.

\subsection{Microbiological Analysis}

The canned cowpeas were analyzed for mesophilic bacteria and for yeast and molds each 2 months. Ten grams of canned peas were removed aseptically from each container and diluted with $90 \mathrm{~mL}$ of sterile peptone water. For aerobic plate counts, after homogenization, samples were serially diluted $\left(10^{-1}-10^{-6}\right)$ with sterile peptone water then enumerated using Nutrient Agar incubated at $35^{\circ} \mathrm{C}$ during $72 \mathrm{~h}$. Yeasts and molds were assessed on rose Bengal after 7 days of incubation at $28^{\circ} \mathrm{C}$. Each test was made in duplicate and results were expressed as colony-forming units (CFU) per gram.

\subsection{Seed Firmness}

Soft sterilized cowpea's hardness was determined after canning and each 2 months using texture analyzer TA-XT2i, Stable Micro Systems Ltd. (Godalming, UK). Seven canned peas were selected to undergo the firmness test. The tests were realized until a deformation of $20 \mathrm{~mm}$, pretest speed of $1.0 \mathrm{~mm} / \mathrm{s}$, and test speed of $0.5 \mathrm{~mm} / \mathrm{s}$ using a cylindrical shape probe(fat as probe base) of $35 \mathrm{~mm}$ end diameter. Hardness value was considered as mean peak compression force and express in $\mathrm{g}$.

\section{$2.5 \mathrm{pH}$ Measurement}

Glass electrode $\mathrm{pH}$ meter was used to determine the $\mathrm{pH}$ of samples. The measurement was done on the drained liquid poured from the can into a beaker. 


\subsection{Leached Solids}

Soluble solids was evaluated throughout the method proposed by Yeung et al. (2009). This method was to determine ${ }^{\circ}$ Brix using a refractometerWAY-2W, Precision and Scientific Instrument co., Ltd (Shanghai, China). Briefly, broth was swirled to disperse solids settling at the bottom then a drop was placed on the prism surface for measurement. Soluble solid loss was calculated with the following formula:

$$
\text { Soluble solids loss }=\left({ }^{\circ} \text { Brix }\right)(\text { final broth weight }) \times 100 / \text { initial seed weight }
$$

The final broth weight was determined by taking the drained weight after drainage throughout a sieve.

\subsection{Proximate Composition}

Crude protein, fat ash, and moisture percentages were determined using (AOAC, 1990) standard methods. Crude carbohydrate was obtained by the following formula:

$$
\text { Crude carbohydrate }=100-(\text { Protein } \%+\text { Fat } \%+\text { Ash } \%+\text { Moisture } \%)
$$

\subsection{Sensory Evaluation}

Twelve trained panelists had evaluated the sensory attributes of canned cowpea. Each 60 days one batch of canned cowpea was chosen randomly for sensory evaluation. Canned cowpea was evaluated for appearance and color, taste, texture and overall acceptability. Panelists used hedonic scale of 9 points to evaluate the canned peas (1-extremely dislike, 2-dislike very much, 3-dislike moderately, 4-dislike slightly, 5-neitheir like nor dislike, 6-like slightly, 7-like moderately, 8-like very much, and 9-extremely like). Canned cowpeas were considered acceptable when their overall mean value was equal or above 5 (neither like nor dislike).

\subsection{Statistical Analysis}

SPSS Inc. software (version 17.0) was used to perfume statistical analysis. One-way analysis of variance (ANOVA) was used to determine significant differences among the mean values, with the significance level taken at $(\mathrm{P}<0.05)$ using Tukey test.

\section{Results and Discussion}

\subsection{Microbiological Analysis}

Table 1 shows that after 10 months of storage, no detectable counts were found in both treated and untreated samples for mold and yeast, however, some colonies of mesophilic bacteria were detected in the control at the 8th and 10th month of storage (2.05 log CFU/g and $4.12 \mathrm{log}$ CFU/grespectively). From these results, it can be concluded that nano- $\mathrm{ZnO}$ and heat have acted synergistically to prevent the growth of microorganisms that could have been in the samples. The results are in agreement with previous studies on antimicrobial efficacy of nano-ZnO (Jin, Sun, Su, Zhang, \& Sue, 2009; Tayel et al., 2011; Xie, He, Irwin, Jin, \& Shi, 2011). Nano-ZnO can therefore be combined with soft sterilization to process commercially ambient stable low foods especially those that the quality characteristics are altered by normal sterilization conditions. However, Leadley et al. (2008) had reported that the absence of detectable counts after processing cannot assure safety from a process establishment perspective, in fact, authors have suggested that a challenge testing with pathogens or a suitable indicator organism would be required to demonstrate a known level of microbial reduction.

Table 1. Microbial analysis of processed cowpea

\begin{tabular}{cccccccc}
\hline \multirow{2}{*}{ Parameters } & Treatment & \multicolumn{7}{c}{ Storage time (Month) } \\
\cline { 2 - 7 } & & 0 & 2 & 4 & 6 & 8 & 10 \\
\hline $\begin{array}{c}\text { Mesophilic } \\
\text { bacteria } \\
\text { (log }\end{array}$ & Control & Nil & Nil & Nil & Nil & $2.05 \pm 0.2$ & $4.12 \pm 0.97$ \\
CFU/g) & samples & Nil & Nil & Nil & Nil & Nil & Nil \\
$\begin{array}{c}\text { Mold and } \\
\text { yeast (log }\end{array}$ & Control & Nil & Nil & Nil & Nil & Nil & Nil \\
CFU/g) & samples & Nil & Nil & Nil & Nil & Nil & Nil \\
\hline
\end{tabular}

$\overline{\text { Values are means and standard deviation of duplicate; Values are significantly different }(\mathrm{P}<0.05) \text { from each }}$ other. 


\subsection{Firmness}

From Figure 1, it can be observed that some softening was observed over the storage time, similar results were reported by Leadley et al. (2008) when they compared the effect of high pressure sterilization and conventional thermal sterilization on the quality of green beans. As shown in Figure 1 the initial hardness values were similar for both control and treated sample. However, on the $6^{\text {th }}$ month of storage the untreated peas started to loss their firmness. This difference in the firmness between the treated peas and untreated became significant $(\mathrm{P}<0.05)$ at the $10^{\text {th }}$ month of storage. This findings corroborate with the results reported by Meng et al. (2014) who found that the firmness of fresh-cut Kiwifruit can be kept while coated with nano-ZnO. Firmness was maintained likely due to the antimicrobial effect of nano-ZnO. Indeed, Hong et al. (2012) had reported that maintenance of firmness in fruits treated with chitosan coatings could be due to their higher anti-fungal activity,however, in the present study no molds had grown in control samples and covering of the cuticle and lenticels. As firmness is one of important quality attributes of canned foods judged by consumers, it can highly affect the product overall acceptance. These results support the fact that the combination between soft sterilization and nano-ZnO can be used as an alternative to the conventional sterilization to process this cowpea variety (TN 5-78).

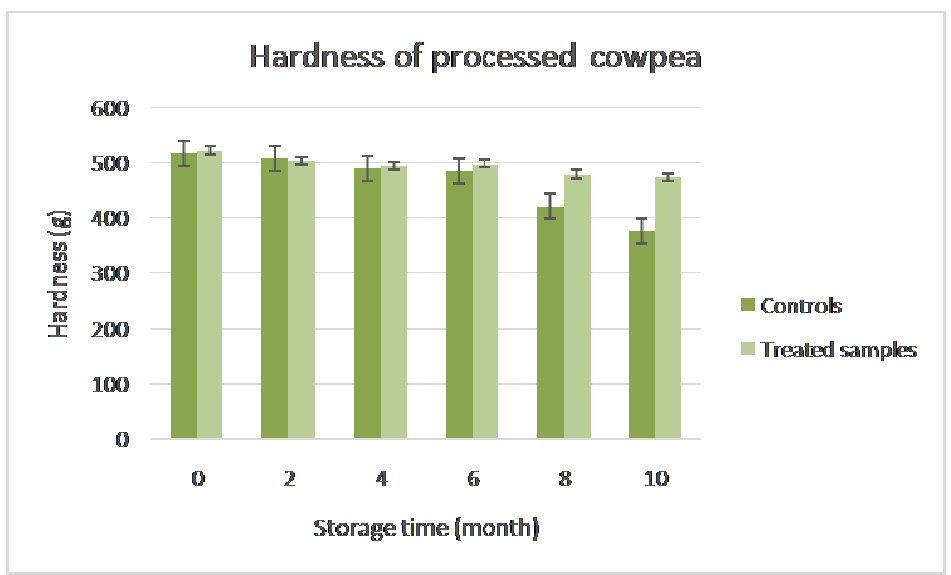

Figure 1. Combined effect of soft sterilization and nano- $\mathrm{ZnO}$ on the hardness of processed cowpea

\subsection{Leached Solids}

Solids leaching is a key parameter in canned food quality keeping during the storage time. Afoakwa et al. (2006) had reported that too high amount of leached solids can bring about low quality and fast deterioration of the canned cowpea. The combination effect of soft sterilization and nano- $\mathrm{ZnO}$ of the solids leaching is shown in Figure 2. From this study, no significant $(\mathrm{P}<0.05)$ differences were observed between both treated and untreated samples for leached solids percentage throughout the storage time.

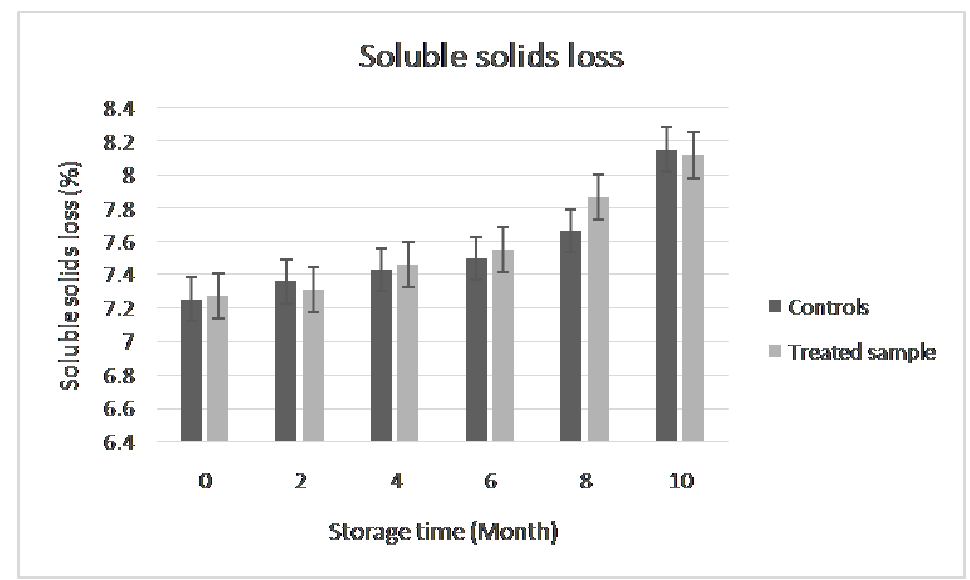

Figure 2. Combined effect of soft sterilization and nano- $\mathrm{ZnO}$ on the soluble solids loss 


\section{$3.4 \mathrm{pH}$}

Canned food's shelf life is strongly affected by their $\mathrm{pH}$ stability because its variation may cause a denaturation of nutrients or bioactive compounds or sometimes promote microbial growth. Minguez and Rojas (1994) reported that carotenoids are quite sensitive to acids. Later, Andrés-Bello et al. (2013) found that pectin shows a high stability in aqueous solutions at $\mathrm{pH}$ 3.0-4.0 Pigments (e.g., chlorophyll, carotenoids, anthocyanins, myoglobin, etc.) responsible for the color of fruits, vegetables and meats can also be affected by $\mathrm{pH}$ as reported by Andrés-Bello et al. (2013). Therefore, $\mathrm{pH}$ can affect texture and color which are important sensory attributes of processed foods. Table 2 shows that there were significant $(\mathrm{P}<0.05)$ difference in the $\mathrm{pH}$ values between treated and untreated samples from the initial time to the 6th month of storage. From the 8th to 10th month of storage, significant differences were observed between nano- $\mathrm{ZnO}$ treated sample and the reference for the $\mathrm{pH}$ values. This may be explained by the microbial growth observed at these periods. The maintaining of $\mathrm{pH}$ in the treated samples can be imputed to the antimicrobial property of nano-ZnO. The results support the fact that nano- $\mathrm{ZnO}$ can be combined to heat in the aim to softly sterilized and extend the shelf life of this cowpea variety.

\subsection{Effect on Proximate Composition}

The combined effect of soft sterilization and nano- $\mathrm{ZnO}$ treatment on the proximate composition of cowpeas is presented in Table 2. The difference between the reference and treated samples were not statistically significant $(\mathrm{P}>0.05)$ for crude carbohydrate ash and fat content from the initial time to the end of storage period. Initially, the protein percentage of treated samples and reference was significantly $(\mathrm{P}<0.05)$ difference. It is shown that the treated sample have $6.07 \%$ as protein content which is lower than that of the control sample $(6.25 \%)$. The reduction of treated sample's protein content may be attributed to their adsorption onto $\mathrm{Zn}$ nano-particules surfaces. The study by Dembereldorj et al. (2012) had revealed that the conformational changes of proteins adsorbed onto $\mathrm{ZnO}$ nanoparticle surfaces were adsorbed onto $\mathrm{ZnO}$ surfaces through both $\mathrm{PO}_{3} \mathrm{H}_{2}$ and $\mathrm{CO}_{2} \mathrm{H}$ head groups. However, from Table 2 it can be noticed that the protein content of treated samples remained stable during the storage time whereas, a significant reduction in the protein content of untreated samples was observed. This result shows the usefulness of nano- $\mathrm{ZnO}$ for the stability of soft sterilized cowpea's proximate composition during storage.

Table 2. Proximate composition and $\mathrm{pH}$ of processed cowpea

\begin{tabular}{|c|c|c|c|c|c|c|c|}
\hline \multirow{2}{*}{$\begin{array}{l}\text { Parameters } \\
(\%)\end{array}$} & \multirow{2}{*}{$\begin{array}{l}\text { samples } \\
\text { Treatment }\end{array}$} & \multicolumn{6}{|c|}{ Storage time (month) } \\
\hline & & 0 & 2 & 4 & 6 & 8 & 10 \\
\hline \multirow[t]{2}{*}{ Protein } & Control & $6.25^{\mathrm{f}} \pm 0.15$ & $6.20^{f} \pm 0.14$ & $5.12^{\mathrm{c}} \pm 0.19$ & $5.75^{\mathrm{d}} \pm 0.36$ & $5.10^{\mathrm{bc}} \pm 0.17$ & $5.04^{\mathrm{abc}} \pm 98$ \\
\hline & Treated & $6.07^{\mathrm{e}} \pm 0.34$ & $6.04^{\mathrm{e}} \pm 0.11$ & $6.05^{\mathrm{e}} \pm 0.17$ & $6.10^{\mathrm{e}} \pm 1.01$ & $6.08^{\mathrm{e}} \pm 1.10$ & $6.03^{\mathrm{e}} \pm 1.31$ \\
\hline \multirow[t]{2}{*}{ Ash } & Control & $0.52^{\mathrm{a}} \pm 0.01$ & $0.51^{\mathrm{a}} \pm 0.04$ & $0.50^{\mathrm{a}} \pm 0.07$ & $0.51^{\mathrm{a}} \pm 0.02$ & $0.48^{\mathrm{a}} \pm 0.15$ & $0.49^{\mathrm{a}} \pm 0.11$ \\
\hline & Treated & $0.48^{\mathrm{a}} \pm 0.08$ & $0.49^{\mathrm{a}} \pm 0.05$ & $0.51^{\mathrm{a}} \pm 0.01$ & $0.49^{\mathrm{a}} \pm 0.01$ & $0.52^{\mathrm{a}} \pm 0.07$ & $0.50^{\mathrm{a}} \pm 0.01$ \\
\hline \multirow[t]{2}{*}{ Carbohydrate } & Control & $18.19^{\mathrm{a}} \pm 1.23$ & $18.65^{\mathrm{ab}} \pm 1.18$ & $19.57^{\mathrm{ab}} \pm 1.98$ & $19.25^{\mathrm{ab}} \pm 2.03$ & $19.21^{\mathrm{ab}} \pm 3.90$ & $19.45^{\mathrm{ab}} \pm 2.01$ \\
\hline & Treated & $19.10^{\mathrm{ab}} \pm 1.91$ & $18.57^{\mathrm{ab}} \pm 0.97$ & $18.74^{\mathrm{ab}} \pm 1.22$ & $20.27^{\mathrm{ab}} \pm 1.12$ & $20.93^{\mathrm{ab}} \pm 1.86$ & $19.98^{\mathrm{ab}} \pm 1.23$ \\
\hline \multirow[t]{2}{*}{ Fat } & Control & $0.53^{\mathrm{b}} \pm 0.03$ & $0.49^{\mathrm{ab}} \pm 0.01$ & $0.53^{\mathrm{b}} \pm 0.10$ & $0.49^{\mathrm{ab}} \pm 0.02$ & $0.49^{\mathrm{ab}} \pm 0.03$ & $0.49^{\mathrm{ab}} \pm 0.02$ \\
\hline & Treated & $0.55^{\mathrm{b}} \pm 0.07$ & $0.45^{\mathrm{a}} \pm 0.03$ & $0.47^{\mathrm{ab}} \pm 0.02$ & $0.47^{\mathrm{ab}} \pm 0.05$ & $0.44^{\mathrm{a}} \pm 0.01$ & $0.46^{\mathrm{a}} \pm 0.03$ \\
\hline \multirow[t]{2}{*}{ Moisture } & Control & $74.54^{\mathrm{a}} \pm 2.35$ & $74.05^{\mathrm{a}} \pm 3.18$ & $74.28^{\mathrm{a}} \pm 2.03$ & $74.00^{\mathrm{a}} \pm 1.98$ & $74.72^{\mathrm{a}} \pm 0.98$ & $74.53^{\mathrm{a}} \pm 3.14$ \\
\hline & Treated & $73.80^{\mathrm{a}} \pm 1.79$ & $74.41^{\mathrm{a}} \pm 0.93$ & $74.23^{\mathrm{a}} \pm 3.64$ & $72.67^{\mathrm{a}} \pm 2.14$ & $72.03^{\mathrm{a}} \pm 2.45$ & $73.03^{\mathrm{a}} \pm 2.13$ \\
\hline \multirow[t]{2}{*}{$\mathrm{pH}$} & Control & $5.95^{\mathrm{bc}} \pm 0.01$ & $5.96^{\mathrm{c}} \pm 0.1$ & $5.92^{\mathrm{bc}} \pm 0.02$ & $5.94^{\mathrm{bc}} \pm 0.13$ & $5.86^{\mathrm{ab}} \pm 0.11$ & $5.82^{\mathrm{a}} \pm 0.07$ \\
\hline & Treated & $6.54^{\mathrm{de}} \pm 0.43$ & $6.55^{\mathrm{de}} \pm 0.04$ & $6.47^{\mathrm{d}} \pm 0.08$ & $6.56^{\mathrm{e}} \pm 0.21$ & $6.48^{\mathrm{de}} \pm 0.12$ & $6.50^{\mathrm{de}} \pm 0.31$ \\
\hline
\end{tabular}

Values are means and standard deviation of triplicate; Values in columnwith different superscripts are significantly different $(\mathrm{P}<0.05)$ from each other $(n=3)$

\subsection{Sensory Qualities}

As shown in Table 3, there were no significant $(\mathrm{P}<0.05)$ differences in the score of appearance, color, and taste, between treated and untreated samples over the storage time. However, significant $(\mathrm{P}<0.05)$ differences were 
recorded for texture score between the two groups of samples from the 6th to the 10th month. The texture scores were decreased by about $28 \%$ and $12.46 \%$ for control and treated sample respectively. The high depreciation of control's texture may be the consequence of the significant loss of firmness observed at that period. Sefa-Dedeh et al. (2001) had reported that for acceptable cowpea product formulation, a firmness level of $500 \mathrm{~g}$ is ideal. Counter to the control, the treated samples were acceptable after 10 month of storage because their overall acceptability score remained in a good range. Similar results were reported by Kumar et al. (2011) on the effect of combination processing on the microbial, chemical and sensory quality of ready-to-eat vegetable pulav. These results show that nano- $\mathrm{ZnO}$ can be combined to heat to produce good quality shelf-stable low-acid foods accepted by consumers.

Table 3. Sensory analysis of combination processed cowpea

\begin{tabular}{llllllll}
\hline Parameters & Samples & \multicolumn{5}{l}{ Storage time (month) } \\
\cline { 3 - 8 } & Treatment & 0 & 2 & 4 & 6 & 8 & 10 \\
\hline Appearance & Control & $7.05^{\mathrm{c}} \pm 0.11$ & $7.03^{\mathrm{c}} \pm 0.03$ & $6.46^{\mathrm{b}} \pm 0.41$ & $6.19^{\mathrm{b}} \pm 0.18$ & $6.28^{\mathrm{b}} \pm 0.45$ & $5.75^{\mathrm{a}} \pm 0.17$ \\
& Treated & $7.05^{\mathrm{c}} \pm 1.02$ & $6.93^{\mathrm{c}} \pm 0.49$ & $6.31^{\mathrm{b}} \pm 0.12$ & $6.30^{\mathrm{b}} \pm 0.35$ & $6.22^{\mathrm{b}} \pm 0.07$ & $5.65^{\mathrm{a}} \pm 0.23$ \\
\multirow{2}{*}{ Texture } & Control & $7.25^{\mathrm{d}} \pm 0.64$ & $7.13^{\mathrm{d}} \pm 1.23$ & $7.14^{\mathrm{d}} \pm 1.74$ & $6.38^{\mathrm{c}} \pm 0.32$ & $5.25^{\mathrm{a}} \pm 0.13$ & $5.15^{\mathrm{a}} \pm 0.21$ \\
& Treated & $7.14^{\mathrm{d}} \pm 1.01$ & $7.18^{\mathrm{d}} \pm 0.67$ & $7.17^{\mathrm{d}} \pm 0.17$ & $7.04^{\mathrm{d}} \pm 1.21$ & $6.37^{\mathrm{c}} \pm 1.11$ & $6.25^{\mathrm{c}} \pm 1.23$ \\
Taste & Control & $7.51^{\mathrm{b}} \pm 0.15$ & $7.28^{\mathrm{b}} \pm 0.48$ & $6.84^{\mathrm{ab}} \pm 0.23$ & $6.24^{\mathrm{ab}} \pm 0.14$ & $5.64^{\mathrm{ab}} \pm 3.51$ & $5.09^{\mathrm{ab}} \pm 0.42$ \\
& Treated & $7.16^{\mathrm{b}} \pm 0.23$ & $7.18^{\mathrm{b}} \pm 0.23$ & $6.76^{\mathrm{ab}} \pm 1.17$ & $4.08^{\mathrm{a}} \pm 1.83$ & $5.33^{\mathrm{ab}} \pm 0.33$ & $5.47^{\mathrm{ab}} \pm 2.07$ \\
Overall & Control & $7.82^{\mathrm{e}} \pm 0.03$ & $7.60^{\text {cde }} \pm 0.18$ & $7.16^{\mathrm{bcd}} \pm 0.23$ & $6.57^{\mathrm{b}} \pm 0.97$ & $5.34^{\mathrm{a}} \pm 0.12$ & $4.95^{\mathrm{a}} \pm 0.54$ \\
acceptability & Treated & $7.75^{\text {cde }} \pm 0.19$ & $7.71^{\text {cde }} \pm 0.09$ & $7.54^{\text {cde }} \pm 0.31$ & $7.40^{\text {cde }} \pm 0.38$ & $7.21^{\text {cde }} \pm 1.25$ & $7.09^{\mathrm{bc}} \pm 0.13$ \\
& & & & & & &
\end{tabular}

Values expressed are mean \pm standard deviation. Values in column with different superscripts are significantly different $(\mathrm{P}<0.05)$ from each other.

\section{Conclusion}

This study showed that $\mathrm{ZnO}$ nano-particules can be used in combination with heat as an alternative for processing and preserving low-acid foods especially for raw foods that the quality parameters are negatively affected during conventional thermal sterilization. The microbiological results obtained in this study suggest that sterilization is possible using nano- $\mathrm{ZnO}$ even when $F_{0}$ value is lower than required. The sensory evaluation revealed that the quality attributes were not affected by nano- $\mathrm{ZnO}$, thus, thetaste and appearance declines strongly, they were maintained in good range over the storage. Thus, this cowpea variety (TN 5-78) can be canned by applying this treatmentthat is best before ten month (shelf live). Further studies are needed to evaluate its efficiency by using specific pathogens in order to reveal whether or not a commercial sterility is reached for a further industrial use of this cowpea variety.

\section{Acknowledgments}

This work was financed by the National Natural Science Foundation of China and the National Science and Technology support program (No 30972058).

\section{References}

Afoakwa, E. O., \& Yenyi, S. E. (2006). Application of response surface methodology for studying the influence of soaking, blanching and sodium hexametaphosphate salt concentration on some biochemical and physical characteristics of cowpeas (Vigna unguiculata) during canning. Journal of Food Engineering, 77(3), 713-724. http://dx.doi.org/10.1016/j.jfoodeng.2005.07.032

Afoakwa, E. O., Yenyi, S. E., \& Sakyi-Dawson, E. (2006). Response surface methodology for optimizing the pre-processing conditions during canning of a newly developed and promising cowpea (Vigna unguiculata) variety. Journal of Food Engineering, 73(4), 346-357. http://dx.doi.org/10.1016/j.jfoodeng.2005.01.037

Amonsou, E., Sakyi-Dawson, E., \& Saalia, F. (2010). Effects of cowpea flour fractionation on sensory qualities and acceptability of kpejigaou (a griddled cowpea paste food). Journal of Food Quality, 33, 61-78. http://dx.doi.org/10.1111/j.1745-4557.2010.00298.x 
Andrés-Bello, A., Barreto-Palacios, V., García-Segovia, P., Mir-Bel, J., \& Martínez-Monzó, J. (2013). Effect of $\mathrm{pH}$ on Color and Texture of Food Products. Food Engineering Reviews, 5(3), 158-170. http://dx.doi.org/10.1007/s12393-013-9067-2

Antonia Murcia, M., Jiménez, A. M., \& Martínez-Tomé, M. (2009). Vegetables antioxidant losses during industrial processing and refrigerated storage. Food Research International, 42(8), 1046-1052. http://dx.doi.org/10.1016/j.foodres.2009.04.012

AOAC. (1990). Official methods of analysis 15th ed. Washington, DC: Association of Official Analytical Chemists. www.abebooks.com/.../official-methods-analysis-association-official-ana

Dembereldorj, U., Ganbold, E.-O., Seo, J. -H., Lee, S. Y., Yang, S. I., \& Joo, S. -W. (2012). Conformational changes of proteins adsorbed onto $\mathrm{ZnO}$ nanoparticle surfaces investigated by concentration-dependent infrared spectroscopy. Vibrational Spectroscopy, 59, 23-28. http://dx.doi.org/10.1016/j.vibspec.2011.12.002

Emamifar, A., Kadivar, M., Shahedi, M., \& Soleimanian-Zad, S. (2010). Evaluation of nanocomposite packaging containing $\mathrm{Ag}$ and $\mathrm{ZnO}$ on shelf life of fresh orange juice. Innovative Food Science \& Emerging Technologies, 11(4), 742-748. http://dx.doi.org/10.1016/j.ifset.2010.06.003

Foh, M., Wenshui, X., Amadou, I., \& Jiang, Q. (2012). Influence of pH Shift on Functional Properties of Protein Isolated of Tilapia (Oreochromis niloticus) Muscles and of Soy Protein Isolate. Food and Bioprocess Technology, 5(6), 2192-2200. http://link.springer.com/article/10.1007\%2Fs11947-010-0496-0\#close

Gutiérrez-Uribe, J. A., Romo-Lopez, I., \& Serna-Saldívar, S. O. (2011). Phenolic composition and mammary cancer cell inhibition of extracts of whole cowpeas (Vigna unguiculata) and its anatomical parts. Journal of Functional Foods, 3(4), 290-297. http://dx.doi.org/10.1016/j.jff.2011.05.004

Hong, K., Xie, J., Zhang, L., Sun, D., \& Gong, D. (2012). Effects of chitosan coating on postharvest life and quality of guava (Psidium guajava L.) fruit during cold storage. Scientia Horticulturae, 144, 172-178. http://dx.doi.org/10.1016/j.scienta.2012.07.002

Jin, T., Sun, D., Su, J. Y., Zhang, H., \& Sue, H. J. (2009). Antimicrobial efficacy of zinc oxide quantum dots against Listeria monocytogenes, Salmonella Enteritidis, and Escherichia coli O157:H7. Journal of Food Science, 74(1), M46-52. http://dx.doi.org/10.1111/j.1750-3841.2008.01013.x

Kumar, R., George, J., Rajamanickam, R., Nataraju, S., Sabhapathy, S. N., \& Bawa, A. S. (2011). Effect of combination processing on the microbial, chemical and sensory quality of ready-to-eat (RTE) vegetable $\begin{array}{llll}\text { pulav. Radiation } & \text { Physics and }\end{array}$ http://dx.doi.org/10.1016/j.radphyschem.2011.06.015

Leadley, C., Tucker, G., \& Fryer, P. (2008). A comparative study of high pressure sterilisation and conventional thermal sterilisation: Quality effects in green beans. Innovative Food Science \& Emerging Technologies, 9(1), 70-79. http://dx.doi.org/10.1016/j.ifset.2007.06.005

Li, X., Li, W., Jiang, Y., Ding, Y., Yun, J., Tang, Y., \& Zhang, P. (2011). Effect of nano-ZnO-coated active packaging on quality of fresh-cut 'Fuji' apple. International Journal of Food Science \& Technology, 46(9), 1947-1955. http://dx.doi.org/10.1111/j.1365-2621.2011.02706.x

Meng, X., Zhang, M., \& Adhikari, B. (2014). The Effects of Ultrasound Treatment and Nano-zinc Oxide Coating on the Physiological Activities of Fresh-Cut Kiwifruit. Food and Bioprocess Technology, 7(1), 126-132. http://dx.doi.org/10.1007/s11947-013-1081-0

Minguez Mosquera, \& Rojas, G. (1994). Mechanism and Kinetics of Carotenoid Degradation during the Processing of Green Table Olives. Journal of Agrlcultural and Food Chemistry, 42, 1551-1556. http://dx.doi.org/10.1021/jf00043a030

Odedeji, J. O., \& Oyeleke, W. A. (2011). Proximate, Physicochemical and Organoleptic Properties of Whole and Dehulled Cowpea Seed Flour (Vigna unguiculata). Pakistan Journal of Nutrition, 10(12), 1175-1178. http://dx.doi.org/10.3923/pjn.2011.1175.1178

Sankhon, A., Amadou, I., Yao, W. R., Wang, H., Qian, H., \& Mlyuka, E. (2014). Effect of different heat-moisture treatment on the physicochemical properties of African locust bean (Parkia biglobosa) starches. Journal of Agricultural Science and Technology, 16(2), 331-342.

Sefa-Dedeh, S., Cornelius, B., Sakyi-Dawson, E., \& Ohene Afoakwa, E. (2003). Application of response surface methodology for studying the quality characteristics of cowpea-fortified nixtamalized maize. Innovative Food Science \& Emerging Technologies, 4(1), 109-119. http://dx.doi.org/10.1016/S1466-8564(02)00070-X 
Sefa-Dedeh, S., Sakyi-Dawson, E., \& Afoakwa, E. O. (2001). Comparative evaluation of cowpea varieties and their performance in a fermented food product. New Orleans, LA, USA.

Tayel, A. A., El-Tras, W. F., Moussa, S., El-Baz, A. F., Mahrous, H., Salem, M. F., \& Brimer, L. (2011). Antibacterial Action of Zinc Oxide Nanoparticles against Foodborne Pathogens. Journal of Food Safety, 31(2), 211-218. http://dx.doi.org/10.1111/j.1745-4565.2010.00287.x

Wang, B., Feng, W., Wang, M., Wang, T., Gu, Y., Zhu, M., ... Wang, J. (2008). Acute toxicological impact of nano- and submicro-scaled zinc oxide powder on healthy adult mice. Journal of Nanoparticle Research, 10(2), 263-276. http://dx.doi.org/10.1007/s11051-007-9245-3

Xie, Y., He, Y., Irwin, P. L., Jin, T., \& Shi, X. (2011). Antibacterial activity and mechanism of action of zinc oxide nanoparticles against Campylobacter jejuni. Applied Environmental Microbiology, 77(7), 2325-2331. http://dx.doi.org/10.1128/AEM.02149-10

Yeung, H., Ehlers, J. D., Waniska, R. D., Alviola, J. N., \& Rooney, L. W. (2009). Rapid screening methods to evaluate cowpea cooking characteristics. Field Crops Research, 112(2-3), 245-252. http://dx.doi.org/10.1016/j.fcr.2009.03.010

\section{Copyrights}

Copyright for this article is retained by the author(s), with first publication rights granted to the journal.

This is an open-access article distributed under the terms and conditions of the Creative Commons Attribution license (http://creativecommons.org/licenses/by/3.0/). 